Revista de Biología Marina y Oceanografía

Vol. 48, №3: 661-665, diciembre 2013

$10.4067 /$ S0718-19572013000300024

Research Note

\title{
Range extension of the non-indigenous alga Mastocarpus sp. along the Southeastern Pacific coast
}

Extensión del rango geográfico del alga foránea Mastocarpus sp. a lo largo de la costa del Pacífico Sudeste

Erasmo C. Macaya ${ }^{1,2}$, Solange Pacheco ${ }^{1}$, Ariel Cáceres ${ }^{1}$ and Selim Musleh ${ }^{1,2}$

${ }^{1}$ Laboratorio de Estudios Algales (ALGALAB), Departamento de Oceanografía, Facultad de Ciencias Naturales y Oceanográficas, Universidad de Concepción, Casilla 160-C, Concepción, Chile. emacaya@oceanografia.udec.cl

${ }^{2}$ Interdisciplinary Center for Aquaculture Research (INCAR), Universidad de Concepción, Concepción, Chile

\begin{abstract}
The red macroalga Mastocarpus sp. (Rhodophyta, Gigartinales) has been reported as a non-indigenous species in central Chile. In this area the geographic range described for the species encompasses approximately $200 \mathrm{~km}$, from Cobquecura $\left(36^{\circ} 08^{\prime} \mathrm{S}, 72^{\circ} 48^{\prime} \mathrm{W}\right)$ up to Punta Lavapié $\left(37^{\circ} 08^{\prime} \mathrm{S}, 73^{\circ} 35^{\prime} \mathrm{W}\right)$. Observations carried out at 22 localities along the central-southern Chilean coast allow us to extend the known range of this species approximately $300 \mathrm{~km}$ to the north and $600 \mathrm{~km}$ to the south. Additional analysis indicated high percentage cover on areas described as the introduction point of the species.
\end{abstract}

Key words: Mastocarpus, geographic range, non-indigenous species, South-eastern Pacific coast

\section{INTRODUCTION}

The arrival of a non-indigenous species to an ecosystem might change the structure of the recipient communities (Schaffelke et al. 2006). In particular, non-indigenous algal species are a major concern because when they become established can impact both the ecosystem structure and function, i.e., altering food webs, monopolizing space and spreading beyond their introduction point (Thresher 2000). Examples include the green alga Caulerpa taxifolia in the Mediterranean (Meinesz et al. 2001), and Codium fragile ssp. tomentosoides in northern Chile which has had negative impacts on the aquaculture of the red alga Gracilaria, affecting farming operations (Neill et al. 2006). This alga has been documented at different sites in Chile from $26^{\circ} \mathrm{S}$ to $55^{\circ} \mathrm{S}$ with faster spread expected towards northern Chile because of its affinity with high temperatures (Neill et al. 2006). The spread of introduced algal species seems to be rapid and characterized by long distance dispersal events (Lyons \& Scheibling 2009).

In Chile, 15 non-indigenous algal species have been described (Castilla \& Neill 2009), and of these, only 2 species are considered invasive: $C$. fragile ssp. tomentosoides (Neill et al. 2006) and Asparagopsis armata (Ramírez et al. 2007). Only C. fragile ssp. tomentosoides has been studied in detail: e.g., taxonomic identity (González \& Santelices 2004), origin (Provan et al. 2005), distributional range and abundance (Neill et al. 2006), biology and ecology (i.e., reproduction and epiphytes: Villaseñor-Parada \& Neill 2011, Villaseñor-Parada et al. 2013). We have a limited understanding of the ecology, biology and distribution in Chilean coastal waters for the remaining species. Mastocarpus sp. (known locally as 'luga gallo' or 'luga-luga') is a red alga from the order Gigartinales, and is a non-indigenous algal species in Chile (Castilla et al. 2005, Castilla \& Neill 2009). The genus' natural distribution is restricted to Pacific coast of North America, the North Atlantic and Japan (Guiry et al. 1984). The first published references of the species in the Southern Hemisphere account from early 1980s by several authors (Alveal \& Romo 1980, Ruiz \& Giampaoli 1981 sampling during 1976, Guiry et al. 1984, Avila \& Alveal 1987). The species was initially reported as M. papillatus, but recent molecular analysis has confirmed it as $M$. latissimus (Lindstrom et al. 2011). The genetic analysis also revealed the closest relationship with samples from California, therefore Lindstrom et al. (2011) suggests a recent anthropogenic dispersal. According to Castilla et al. (2005), the species first arrived during early 1980s on the hulls of ships associated with coal transport. This species is found from the low to mid intertidal (as a foliose gametophyte) to the subtidal (as a tetrasporophytic crust) on rocks at protected and semi-protected habitats, and is occasionally harvested for carrageenan extraction (Hoffmann \& Santelices 1997). 
The species distribution in Chile has been recorded as restricted only to the Biobío Region in Central Chile along $200 \mathrm{~km}$ approximately, between Cobquecura (36 ${ }^{\circ} 10^{\prime} \mathrm{S}$ $72^{\circ} 49^{\prime} \mathrm{W}$ ) and Punta Lavapié (37 $08^{\circ} \mathrm{S}-73^{\circ} 35^{\prime} \mathrm{W}$ ) (Guiry et al. 1984, Avila \& Alveal 1987, Ramírez \& Santelices 1991, Hoffmann \& Santelices 1997). Little is known about the species' present geographic distribution, abundance and effects on local flora and fauna. Recently, Oróstica et al. (2012) reported that detached blades and papillae provide an alternative dispersal mechanism that might facilitate the establishment of individuals at new places. This alternative dispersal mechanism and formation of cistocarpic plants in the absence of male gametophytes (Avila \& Alveal 1987) could facilitate geographic expansion and invasion of new territory. The aim of this paper is to provide new information about the distribution of the non-indigenous species Mastocarpus sp. in Chilean coastal waters, and about its abundance relative to other species in the intertidal.

\section{MATERIALS AND METHODS}

This study was carried out along the central-southern Chilean coast between Valparaíso (32 ${ }^{\circ} 57^{\prime}$ S, $71^{\circ} 32^{\prime} \mathrm{W}$ ) and Melinka (435' $\left.53^{\prime}, 73^{\circ} 44^{\prime} \mathrm{W}\right)$. Twenty-two sites were sampled (Fig. 1) in January/February 2011 and January 2012 and 2013. In order to assess the presence of Mastocarpus sp. in the intertidal, visual surveys were carried out carefully at each site during low tide at rocky platforms and intertidal pools. In addition, percentage cover of Mastocarpus sp. and other algae (Rhodophyta, Chlorophyta and Phaeophyceae) and animals (Cirripedia) was measured using digital photos from 10 quadrats $(25 \times 25$ $\mathrm{cm})$ at each site. The positioning of the quadrats was random but limited to the mid and low intertidal where Mastocarpus sp. typically occurs. Such measurement was restricted at 6 sites of the center species distribution (Curanipe to Lebu), since the sampled sites represent the actual geographic range and the potential introduction point. Percentage cover analyses were carried out using

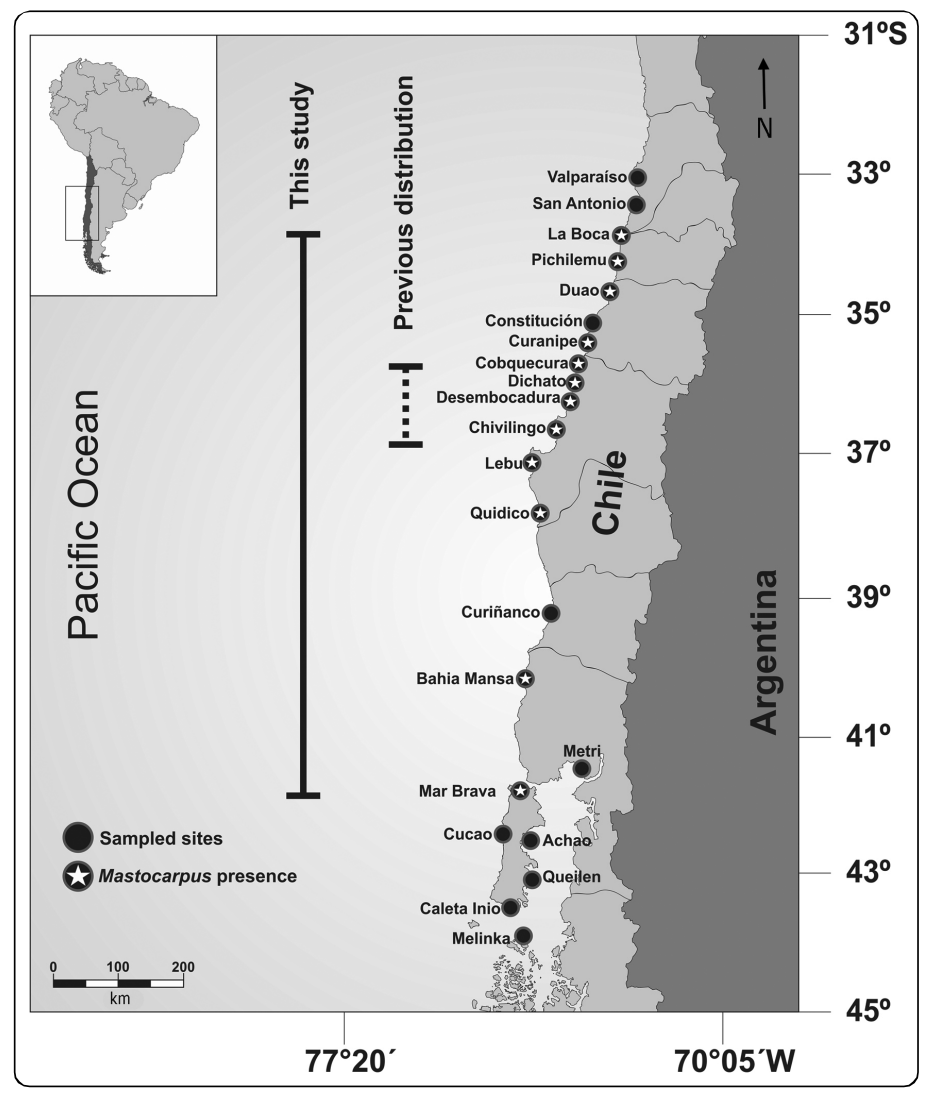

Figure 1. Survey sites at Central-Southern Chile. Circles with stars indicate presence of Mastocarpus sp. The dashed lines represents the previous geographic range, whereas continuous line represents the current distribution / Sitios de observación en Chile Centro-Sur. Círculos con estrellas indican la presencia de Mastocarpus sp. Línea punteada representa la distribución descrita, mientras que la línea continua representa la distribución luego de este estudio 
the Coral Point Count with Excel extensions (CPCe) program Version 4.1 (Kohler \& Gill 2006). A one-way ANOVA was carried out to detect differences in Mastocarpus sp. cover among sites. Significant differences detected by the analysis were explored with Tukey's HSD a posteriori test. The assumption of normality of the data was checked with the KolmogorovSmirnov test and homogeneity of variances with Levene's test. Percentage cover data were arcsine-square roottransformed to achieve normality.

\section{RESULTS AND DISCUSSION}

Mastocarpus sp. was found in 10 of the 22 sites surveyed, and its geographic range increased approximately $300 \mathrm{~km}$ northward, to La Boca (335'⒊49"S; 71'50’32.25"W) and $600 \mathrm{~km}$ southward, to Mar Brava in Chiloé Island (41 ${ }^{\circ} 52^{\prime}$ '5.72"S; 74²'15.30"W) from previous descriptions (Avila \& Alveal 1987, Ramírez \& Santelices 1991, Hoffmann \& Santelices 1997). Similarly, Ramírez et al. (2007) have reported a range extension of 300-400 km for another nonindigenous species along the Chilean coast, the red alga Asparagopsis armata, which is considered invasive (Chualain et al. 2004). Results from our study revealed that in the central area of the distributional range of Mastocarpus sp. (Dichato 36 32'26.78"S; 7256'04.84"W) percentage cover was highest ( 60\% Mastocarpus sp.: ANOVA F=16.37, $P<0.0001$, Tukey post-hoc). From this central region, percentage cover declined in both directions with other algal groups (mainly Gigartinales and Chlorophyta) becoming more dominant. At most sites algal groups and barnacles (Cirripedia) were evenly distributed (Fig. 2). Lebu (37³5'35.8'S; 7340'03.57"W) displayed the lowest Mastocarpus sp. cover with $\sim 2 \%$, whereas the green algae (Ulva spp.) were more abundant ( 90\%), however this site experienced a co-seismic uplift of approximately $1.7 \mathrm{~m}$ after the 27 February 2010 earthquake (Vargas et al. 2011) and at the time of the surveys (one year after earthquake) the distribution of intertidal species might still reflect the changes produced by this major disturbance; Ulva commonly appears in the rocky intertidal zone after disturbances (e.g., Sousa 1979a, b, Dawson \& Foster 1982, Kim \& DeWreede 1996).

The highest cover of Mastocarpus sp. at the center of its distributional range might be confirmation of the suggested introduction point, particularly as major ports are nearby (e.g., Lirquén, San Vicente, Talcahuano) and the area experiences intense shipping activity (Muñoz \& Salamanca 2001); as mentioned above, arrival was most likely associated with hulls of coal ships (Castilla et al. 2005). Williams \& Smith (2007) have suggested boat traffic as one of the major causes of marine algal introduction. Similarly, invasion of the brown alga Undaria pinnatifida in several places probably originated from transport on ship hulls (Chapman et al. 2006). Another introduction mechanism such aquaculture activity can't be ruled out, but are less likely since the area lacks dispersal vectors (e.g., imported species from the northeast Pacific).

Our data suggest that, since the first reports in the early 1980s of Mastocarpus sp. in Chilean waters, an

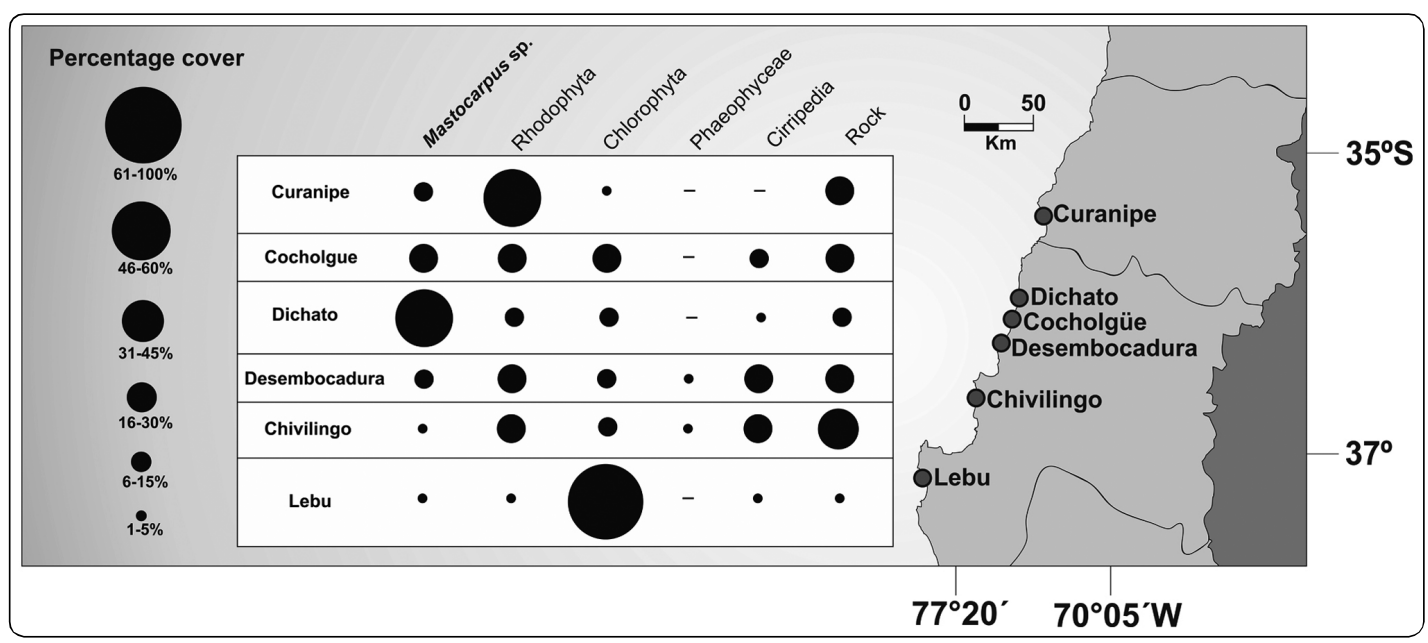

Figure 2. Percentage cover of Mastocarpus sp., other algal groups (red - M astocarpus sp. excluded, green and brown algae), Cirripedia, and rocky substrate of each site at the centre of the alga's distributional range / Porcentaje de cobertura de Mastocarpus sp., otros grupos algales (algas rojas -no incluye Mastocarpus sp., verdes y pardas), Cirripedia y sustrato rocoso en cada sitio, al centro del rango de distribución del alga 
expansion of an average of 10 and $20 \mathrm{~km}$ year ${ }^{-1}$ has occurred towards north and south respectively (assuming a constant rate of spread over the intervening years, and no previous record of the species in Chilean waters, for such reason the results must to be taken in account with caution). However, expansion rates are variable and depend on several biotic and abiotic factors, such as life history traits and interactions with other species, etc., (see Lyons \& Scheibling 2009 for details), and can be unpredictable even within the same species at different times and geographic regions. The expansion of Mastocarpus sp. is slower in comparison with other invasive species such as Codium fragile ssp. tomentosoides and Undaria pinnatifida, but similar to that of the red alga Grateloupia turuturu in North America (21 $\pm 4 \mathrm{~km} \mathrm{year}^{-1}$ ) (Lyons \& Scheibling 2009). Cover values of Mastocarpus sp. along the Chilean coast indicates that although the alga has become established, it has not competitively displaced native species in most places. For example, in both extremes of its geographic range individuals of Mastocarpus sp. are scarce, with approximately 1-2 individuals per $\mathrm{m}^{2}$ (Macaya E, pers. observ.). Although the species seems to disperse naturally (Oróstica et al. 2012), biotic and abiotic factors might also restrict the rapid growth and colonization and additional studies need to be carried out. Temperature is unlikely to represent a barrier along the Chilean coast since the genus is distributed in seawater ranging from 3 to $23^{\circ} \mathrm{C}$ (Bell 1993). The species is also extracted by local fishermen, possibly hindering its growth and distribution.

Our understanding of environmental impacts caused by non-indigenous algal species in Chilean waters is still limited; harmful effects might vary over time and geographically as introduced species expand their ranges from their initial introduction points (Chapman et al. 2006). Future studies should examine the ecological interactions of a range of invasive algal species with native flora/ fauna. Patches of Mastocarpus sp. appear to have, for example, a high diversity of associated fauna (Macaya et al. unpublished data). Additionally, future approaches could also include genetic analysis of the species along the geographic range in Chile, therefore identifying the possibility of a single or multiple introductions from its native range in the North Pacific. The value of the molecular techniques in such assignment has been successfully studied in several algae (Voisin et al. 2005, Uwai et al. 2006, Cheang et al. 2010). Finally this article highlights the importance of distributional survey studies in providing baseline information on changes in native and non-native communities.

\section{ACKNOWLEDGMENTS}

This research was supported by FONDECYT project 11110437 (CONICYT) to ECM. We are grateful to Parque Tantauco crew for their support during the field trip to Inio (Chiloé Island), to Ceridwen Fraser and three anonymous reviewers for valuable comments on the manuscript.

\section{LITERATURE CITED}

Alveal K \& H Romo. 1980. Aspectos ecológicos de las algas marinas de la provincia de Concepción, Chile. Boletim do Instituto Oceanográfico 29: 27-29.

Avila M \& K Alveal. 1987. The life history of Mastocarpus papillatus from the area of Concepción, Chile. Investigación Pesquera 34: 129-138.

Bell EC. 1993. Photosynthetic response to temperature and desiccation of the intertidal alga Mastocarpus papillatus. Marine Biology 117: 337-346.

Castilla JC \& PE Neill. 2009. Marine bioinvasions in the Southeastern Pacific: status, ecology, economic impacts, conservation and management. In: Rilov G \& JA Crooks (eds). Biological invasions in marine ecosystems, pp. 439457. Springer, Berlin.

Castilla JC, M Uribe, $\mathbf{N}$ Bahamonde, M Clarke, $\mathbf{R}$ Desqueyroux-Faundez, I Kong, H Moyano, N Rozbaczylo, B Santelices, C Valdovinos \& P Zavala. 2005. Down under the southeastern Pacific: marine nonindigenous species in Chile. Biological Invasions 7: 213232.

Chapman D, M Ranelletti \& S Kaushik. 2006. Invasive marine algae: An ecological perspective. The Botanical Review 72: 153-178.

Cheang CC, KH Chu, D Fujita, G Yoshida, M Hiraoka, A Critchley, HG Choi, D Duan, Y Serisawa \& PO Ang. 2010. Low genetic variability of Sargassum muticum (Phaeophyceae) revealed by a global analysis of native and introduced populations. Journal of Phycology 46: 10631074.

Chualain FN, CA Maggs, GW Saunders \& MD Guiry. 2004. The invasive genus Asparagopsis (Bonnemaisoniaceae, Rhodophyta): Molecular systematics, morphology, and ecophysiology of Falkenbergia isolates. Journal of Phycology 40: 1112-1126.

Dawson EY \& MS Foster. 1982. Seashore plants of California, 226 pp. University of California Press, California.

González A \& B Santelices. 2004. A dichotomous species of Codium (Bryopsidales, Chlorophyta) is colonizing northern Chile. Revista Chilena de Historia Natural 77: 293-304.

Guiry MD, JA West, DH Kim \& M Masuda. 1984. Reinstatement of the genus Mastocarpus Kützing (Rhodophyta). Taxon 33: 53-63. 
Hoffmann A \& B Santelices. 1997. Flora marina de Chile central, 434 pp. Ediciones Universidad Católica de Chile, Santiago.

Kim JH \& RE DeWreede. 1996. Effects of size and season of disturbance on algal patch recovery in a rocky intertidal community. Marine Ecology Progress Series 133: 217-228.

Kohler KE \& SM Gill. 2006. Coral point count with Excel extensions (CPCe): A visual basic program for the determination of coral and substrate coverage using random point count methodology. Computers and Geosciences 32: 1259-1269.

Lindstrom SC, JR Hughey \& PT Martone. 2011. New, resurrected and redefined species of Mastocarpus (Phyllophoraceae, Rhodophyta) from the northeast Pacific. Phycologia 50: 661-683.

Lyons DA \& RE Scheibling. 2009. Range expansion by invasive marine algae: rates and patterns of spread at a regional scale. Diversity and Distributions 15: 762-775.

Meinesz A, T Belsher, T Thibaut, B Antolic, KB Mustapha, C-F Boudouresque, D Chiaverini, F Cinelli, J-M Cottalorda, A Djellouli, A El Abed, C Orestano, AM Grau, L Ivesa, A Jaklin, H Langar, E Massuti-Pascual, A Peirano, L Tunesi, J de Vaugelas, N Zavodnik \& A Zuljevic. 2001. The introduced green alga Caulerpa taxifolia continues to spread in the Mediterranean. Biological Invasions 3: 201-210.

Muñoz P \& M Salamanca. 2001. Flujo de plomo particulado a los sedimentos marinos y su incorporación en Paraprionospio pinnata (Polychaeta: Spionidae) en Bahía Concepción (36 ${ }^{\circ}$ Lat. S), Chile. Gayana 65: 155-166.

Neill PE, O Alcalde, S Faugeron, SA Navarrete \& JA Correa. 2006. Invasion of Codium fragile ssp. tomentosoides in northern Chile: Anew threat for Gracilaria farming. Aquaculture 259: 202-210.

Oróstica MH, RD Otaíza \& PE Neill. 2012. Blades and papillae as likely dispersing propagules in Chilean populations of Mastocarpus sp. (Rhodophyta, Gigartinales). Revista de Biología Marina y Oceanografía 47: 109-119.

Provan JIM, S Murphy \& CA Maggs. 2005. Tracking the invasive history of the green alga Codium fragile ssp. tomentosoides. Molecular Ecology 14: 189-194.

Ramírez ME \& B Santelices. 1991. Catálogo de las algas marinas bentónicas de la costa temperada del Pacífico de Sudamérica, 437 pp. Monografías Biológicas 5, Facultad de Ciencias Biológicas, Pontificia Universidad Católica de Chile, Santiago.

Ramírez ME, R García-Huidobro \& F Goecke. 2007. Extensión del límite sur de distribución de Asparagopsis armata Harvey (Bonnemaisoniales, Rhodophyta) en la costa de Chile continental, una especie invasora en el Mediterráneo. Noticiario Mensual, Museo Nacional de Historia Natural, Chile 359: 23-29.

Ruiz E \& L Giampaoli. 1981. Estudios distribucionales de la flora y fauna costera de caleta Cocholgue, Bahía de Concepción-Chile. Boletín de la Sociedad de Biología de Concepción 52: 145-166.

Schaffelke B, JE Smith \& CL Hewitt. 2006. Introduced macroalgae- a growing concern. Journal of Applied Phycology 18: 529-541.

Sousa WP. 1979a. Disturbance in marine intertidal boulder fields: the nonequilibrium maintenance of species diversity. Ecology 60: 1225-1239.

Sousa WP. 1979b. Experimental investigations of disturbance and ecological succession in a rocky intertidal algal community. Ecological Monographs 49: 227-254.

Thresher RE. 2000. Key threats from marine bioinvasions: a review of current and future issues. In: Marine bioinvasions, Proceedings of the First National Conference, January 2427, 1999, pp 24-36. Massachusetts Institute of Technology, Sea Grant College Program, Boston.

Uwai S, W Nelson, K Neill, WD Wang, LE Aguilar-Rosas, SM Boo, T Kitayama \& H Kawai. 2006. Genetic diversity in Undaria pinnatifida (Laminariales, Phaeophyceae) deduced from mitochondria genes - origins and succession of introduced populations. Phycologia 45: 687-695.

Vargas G, M Farías, S Carretier, A Tassara, S Baize \& D Melnick. 2011. Coastal uplift and tsunami effects associated to the $2010 \mathrm{Mw} 8.8$ Maule earthquake in Central Chile. Andean Geology 38: 219-238.

Villaseñor-Parada C \& PE Neill. 2011. Spatial distribution of epiphytes along the thallus of the introduced macroalga, Codium fragile subsp. tomentosoides in the subtidal zone of Caldera. Revista de Biología Marina y Oceanografía 46: 257-262.

Villaseñor-Parada C, EC Macaya, LM Jara-Rojas \& PE Neill. 2013. Variación espacial y temporal en la producción de gametangios en la macroalga exótica Codium fragile subsp. tomentosoides (Chlorophyta: Bryopsidales) en el submareal de Caldera. Revista de Biología Marina y Oceanografía 48: 213-218.

Voisin M, CR Engel \& F Viard. 2005. Differential shuffling of native genetic diversity across introduced regions in a brown alga: Aquaculture vs. maritime traffic effects. Proceedings of the National Academy of Sciences of the United States of America 102: 5432-5437.

Williams SL \& JE Smith. 2007. A global review of the distribution, taxonomy, and impacts of introduced seaweeds. Annual Review of Ecology Evolution and Systematics 38: 327-359.

Received 21 June 2013 and accepted 26 September 2013

Associate Editor: Pilar Muñoz M. 